\title{
PENGARUH MULTIMEDIA INTERAKTIF TERHADAP HASIL BELAJAR SISWA PADA KOMPETENSI PERBAIKAN DIFFERENTIAL
}

\author{
Fatwa T. Radityan ${ }^{1}$, Iwa Kuntadi ${ }^{2}$, Mumu Komaro ${ }^{3}$ \\ Departemen Pendidikan Teknik Mesin \\ Universitas Pendidikan Indonesia \\ Jl. Dr. Setiabudhi No. 207 Bandung 40154 \\ radityanhaner@gmail.com
}

\begin{abstract}
ABSTRAK
Tujuan penelitian ini adalah untuk mengetahui pengaruh multimedia interaktif terhadap hasil belajar siswa setelah melakukan proses pembelajaran. Penelitian ini dilakukan dengan menggunakan metode quasi experiment dengan desain non equivalent control group design. Populasi dalam penelitian ini adalah siswa kelas XI SMKN 6 Bandung kompetensi keahlian teknik kendaraan ringan yang berjumlah 70 siswa. Instrumen yang digunakan pada penelitian ini berupa soal pre test yang dilaksanakan sebelum siswa melaksanakan proses pembelajaran dan post test setelah siswa melaksanakan proses pembelajaran, kedua soal tes tersebut digunakan untuk melihat peningkatan hasil belajar siswa. Peningkatan hasil belajar siswa yang menggunakan multimedia interaktif yaitu 0,67 lebih tinggi dibandingkan pembelajaran menggunakan media visual dengan peningkatan 0,41 , sehingga dapat disimpulkan bahwa multimedia interaktif mempunyai pengaruh yang signifikan terhadap hasil belajar siswa pada kompetensi perbaikan differential.
\end{abstract}

Kata kunci: multimedia, interaktif, differential, kompetensi.

\section{PENDAHULUAN}

Media pembelajaran berfungsi untuk menyampaikan pesan pembelajaran serta memperjelas penyajian pesan, mengatasi keterbatasan ruang dan waktu dan memungkinkan interaksi belajar mengajar yang lebih bervariasi dan bergairah. Pemanfaatan media pembelajaran tersebut diharapkan akan membawa pengaruh positif terhadap hasil belajar siswa agar tercapai tujuan pembelajaran (Arsyad, 2010).

Berdasarkan pengalaman ketika melaksanakan program pengalaman lapangan (PPL) di SMK N 6 Bandung. Kompetensi perbaikan differential merupakan salah satu pelajaran yang diajarkan, proses pembelajarannya masih menggunakan media visual ini disebabkan karena keterbatasan media yang ada, sehingga tidak semua siswa dapat memahami pelajaran yang disampaikan oleh guru, selain itu siswa kurang antusias dalam proses pembelajaran dikarenakan jenuh karena terlalu berpusat pada guru proses pembelajarannya. Seperti dapat dilihat dari data hasil evaluasi belajar siswa tingkat II tahun ajaran 2012/2013 pada kompetensi perbaikan differential menunjukan bahwa hasil belajar siswa masih rendah, dan

\footnotetext{
${ }^{1}$ Mahasiswa Departemen Pendidikan Teknik Mesin FPTK UPI

${ }^{2}$ Dosen Departemen Pendidikan Teknik Mesin FPTK UPI

${ }^{3}$ Dosen Departemen Pendidikan Teknik Mesin FPTK UPI
} 
distribusinya pun tidak merata, sedangkan KKM dari kompetensi perbaikan differential adalah 76,00 .

Salah satu media pembelajaran jenis audio visual gerak adalah media pembelajaran multimedia interaktif yang terdiri dari beberapa media yang terintegrasi, antara lain: gambar, suara, animasi dan tulisan. Penerapan multimedia interaktif ini terhadap proses pembelajaran mempunyai kelebihan dalam memperjelas penyajian pesan pembelajaran selain itu lebih efektif dan efisien dalam penggunaannya terhadap kompetensi perbaikan differential (Musfiqon, 2012). Hal ini karena karakteristik dari materi pelajaran dari kompetensi tersebut yang banyak menjelaskan tentang definisi, wujud, fungsi dan proses kerja dari differential. Differential merupakan salah satu bagian dari sistem pemindah tenaga yang berfungsi untuk meneruskan putaran dari profeller shaft ke axle shaft, selain itu differential juga berfungsi untuk membedakan putaran roada ketika kendaraan berbelok. Multimedia ini dapat menjelaskan secara konkrit cara kerja differential ketika sedang membedakan putaran antara roda kiri dan kanan selain itu wujud dari differential dan komponen-komponennya yang dapat ditampilkan secara realistik, proses kerja dari sistem juga dapat ditampilkan lebih konkrit karena menggunakan animasi. Penggunaan multimedia interaktif ini juga dapat menghemat waktu maupun biaya dalam proses pembelajaran namun multimedia interaktif ini juga masih mengacu pada tujuan pembelajaran.

Tujuan penelitian ini, yaitu untuk engetahui hasil belajar siswa pada kompetensi perbaikan differential dengan menggunakan multimedia interaktif dan visual, serta hasil belajar siswa yang menggunakan multimedia interaktif dengan yang menggunakan media visual. Multimedia interaktif presentasi digunakan untuk menjelaskan materi-materi yang sifatnya teoritis dan digunakan dalam pembelajaran klasikal, baik kelompok kecil maupun besar. Media ini cukup efektif sebab menggunakan multimedia projector (lcd/viewer) yang memilki jangkauan pancar cukup besar. Pemanfaatan mulimedia dalam presentasi ini biasanya menggunakan perangkat lunak komputer yaitu powerpoint, flash macromedia.

Kelebihan multimedia presentasi, yaitu: mampu menampilkan objek-objek yang sebenarnya tidak ada secara fisik atau diistilahkan dengan imagery (Sadiman, 2008). Secara kognitif pembelajaran dengan menggunakan mental imagery akan meningkatkan retensi siswa dalam mengingat materi-materi pelajaran. Memiliki kemampuan dalam menggabungkan semua unsur media seperti teks, video, animasi, image, garfik, dan sound menjadi satu kesatuan penyajian yang terintegrasi. Memilki kemampuan dalam mengakomodasi siswa sesuai dengan modalitas belajarnya, terutama bagi mereka yang memilki tipe viusal, auditif, 
kinestetik, atau yang lainnya. Mampu mengembangkan materi pembelajaran terutama membaca dan mendengarkan secara mudah. Pertama, pada pengembangan materi pembelajaran keterampilan membaca, program aplikasi presentasi dapat dibuat guru (presenter) dengan cara memasukan teks dalam slide pertama, kemudian memasukan latihan dalam dalam slide kedua dan umpan balik latihan dalam slide berikutnya. Untuk memperindah tampilan teks-teks bacaan juga bisa dilengkapi dengan berbagai gambar. Kedua, pada pengembangan materi pembelajaran keterampilan mendengarkan, guru dapat membuat bahan pembelajaran dengan video maupun audio. Seperti halnya pada membaca materi pembelajaran, latihan-latihan dan umpan balik dapat diberikan di slide-slide yang berbeda. Fasilitas hyperlink yang memungkinkan program dihubungkan dengan jaringan internet akan memperkaya penyediaan bahan pembelajaran (Munadi, 2008).

Multimedia presentasi dapat menjelaskan pelajaran yang bersifat teoritis yang sulit untuk dijelaskan dengan visual saja karena materi perbaikan differential banyak menjelaskan proses kerja sehingga siswa dapat dengan jelas memahami materi yang disampaikan karena kelebihan media ini dapat menggabungkan semua unsur media dengan bantuan komputer.

Hasil belajar merupakan bentuk akhir yang dicapai oleh siswa setelah melakukan proses pembelajaran, hasil belajar ini berupa kemampuan intelektual siswa yang terdiri dari beberapa ranah antara lain kognitif, afektif dan psikomotor, namun pada penelitian ini hasil belajar ranah kognitif yang dikhususkan pada kompetensi perbaikan differential yang didapat siswa setelah melakukan pembelajaran menggunakan multimedia interaktif.

Standar kompetensi perbaikan differential adalah salah satu standar kompetensi siswa kelas XI SMKN 6 Bandung yang membahas mengenai definisi differential, prinsip kerja differential, jenis differential, komponen-komponen differential, cara kerja differential dan perbaikan pada differential.

\section{METODE PENELITIAN}

Metode yang digunakan adalah metode kuasi eksperimen. Selama melakukan eksperimen, siswa merupakan objek penelitian yang tetap mengikuti pelajaran dalam kelas seperti biasa. Selain itu, pemilihan objek penelitian juga tidak dilakukan secara acak. Desain penelitian yang digunakan dalam penelitian ini adalah (Non Equivalent Control Group Design) yaitu menempatkan subjek penelitian ke dalam dua kelompok kelas yang terdiri dari kelompok eksperimen dan kelompok kontrol yang tidak dipilih secara acak. Mekanisme penelitian dari ke dua kelas tersebut, sebagai berikut: tes awal yang diberikan pada kelompok 
eksperimen dan kontrol sebelum pembelajaran. Pembelajaran kompetensi perbaikan differential dengan menggunakan multimedia interaktif pada kelas eksperimen dan media visual pada kelas kontrol. Tes akhir yang diberikan pada kelompok eksperimen dan kelas kontrol setelah pembelajaran.

\section{HASIL PENELITIAN}

Penelitian dilakukan terhadap siswa kelas XI SMKN 6 Bandung Program Studi Teknik Kendaraan Ringan, dengan sampel kelas XI TKR 6 untuk kelas eksperimen yang menggunakan multimedia interaktif berjumlah 35 orang dan kelas XI TKR 5 untuk kelas kontrol yang menggunakan media visual berjumlah 35 orang. Data yang diperoleh pada penelitian ini berupa data pre test data post test pada kelas eksperimen dan kelas kontrol.

Data pre test memberikan gambaran kemampuan awal siswa sebelum memperoleh materi pelajaran, khususnya kompetensi perbaikan differential. Data pre test ini juga digunakan untuk mendapatkan tingkat homogenitas dari kedua sampel dalam penelitian, yakni kelas kontrol dan kelas eksperimen. Agar penelitian eksperimen bisa dilakukan maka kedua sampel yang akan diteliti harus homogen (Tabel 1). Data post test memberikan gambaran kemampuan akhir siswa setelah melakukan pembelajaran. Data post test ini diperoleh dari tes tertulis dengan jenis tes dan jumlah soal sama seperti pada pre test.

Tabel 1. Data Hasil Pre Test dan Pos test

\begin{tabular}{lcccc}
\hline \multirow{2}{*}{ Kelas } & \multicolumn{2}{c}{ Kontrol } & \multicolumn{2}{c}{ Eksperimen } \\
\cline { 2 - 5 } & Pre test & Pos test & Pre test & Pos test \\
\hline Nilai tertinggi & 72 & 84 & 76 & 96 \\
Nilai terendah & 20 & 60 & 28 & 68 \\
Rata-rata & 50,06 & 72,80 & 53,03 & 83,54 \\
Interpetasi & Sangat kurang & Kurang & Sangat Kurang & Cukup \\
\hline
\end{tabular}

Berdasarkan data di atas dapat dilihat bahwa kemampuan awal siswa pada kelas kontrol lebih tinggi dibandingkan dengan kelas eksperimen. Rata-rata kemampuan awal pada kelas kontrol sebesar 53,03 sedangkan pada kelas eksperimen sebesar 50,06 yang berada pada interpretasi sangat kurang.

Data post test berdasarkan tabel diatas menunjukkan rata-rata kemampuan penguasaan materi pada kelas eksperimen lebih tinggi dibandingkan dengan kelas kontrol. Rata-rata 
kemampuan siswa pada kelas kontrol (pembelajaran dengan media visual) didapatkan ratarata sebesar 72,80 yang berada pada interpretasi kurang, sedangkan kemampuan rata-rata pada kelas eksperimen (pembelajaran dengan multimedia interaktif) didapatkan rata-rata sebesar 83,54 yang berada pada interpretasi cukup.

Data $N$-Gain diperoleh dari hasil perhitungan dengan menggunakan data dari pre test dan post test. Data $\mathrm{N}$-Gain menunjukkan peningkatan kemampuan siswa setelah mengikuti pembelajaran. Data pada tabel 2, menunjukkan bahwa rata-rata peningkatan hasil belajar siswa di kelas ekperimen lebih tinggi dibandingkan kelas kontrol. Pada kelas kontrol didapatkan rata-rata sebesar 0,67 (67\%), sedangkan rata-rata $N$-Gain pada kelas eksperimen sebesar $0,41(41 \%)$.

Tabel 2. Peningkatan Hasil Belajar

\begin{tabular}{lcccc}
\hline \multicolumn{1}{c}{ Kelas } & Peningkatan & Peningkatan & Rata-rata & N-gain \\
\hline Eksperimen & 52 & 12 & 33,49 & 0,67 \\
Kontrol & 32 & 4 & 19,77 & 0,41 \\
\hline
\end{tabular}

\section{PEMBAHASAN}

Hasil belajar siswa dapat diketahui dengan melakukan beberapa tahapan yaitu pre test, treatment dan post test. Hasil belajar siswa dapat diperoleh setelah melakukan proses pembelajaran tang di ukur melalui tes, tes ini dilakukan dua kali yang pertama pre test (tes sebelum melakukan pembelajaran) dan post test (tes setelah melakukan proses pembelajaran).

Kemampuan awal siswa sebelum melakukan proses pembelajaran dapat dilihat pada diagram dibawah ini, diagram tersebut menunjukkan bahwa tidak ada perbedaan yang signifikan kemampuan awal siswa sebelum menerima materi pembelajaran antara kelas eksperimen dan kelas kontrol. Hal ini terbukti dengan dilakukan uji homogenitas data pre test yang menunjukkan bahwa kedua kelas tersebut homogen namun hasil belajar siswa masih dalam interpretasi sangat kurang atau masih dibawah KKM.

Perbedaan yang signifikan terlihat pada hasil post test yang dilaksanakan setelah proses pembelajaran. Pada diagram diatas terlihat nilai rata-rata post test siswa kelas eksperimen yang menggunakan multimedia interaktif lebih tinggi dibandingkan nilai rata-rata post test kelas kontrol yang menggunakan media visual. Nilai rata-rata post test kelas eksperimen berada pada interpretasi cukup sedangkan kelas kontrol berada pada interpretasi 
kurang. Siswa kelas eksperimen mendapatkan nilai lebih tinggi. Pemerolehan hasil belajar melalui indera pandang sekitar $75 \%$, melalui indera dengar sekitar $13 \%$ dan melalui indera lainnya sekitar 12\%, (Sadiman, 2008).

Data menunjukkan rata-rata peningkatan hasil belajar siswa kelas eksperimen yang menggunakan multimedia interaktif lebih tinggi dibandingkan dengan rata-rata peningkatan hasil belajar siswa kelas kontrol yang menggunakan media visual. Hal ini terbukti dengan uji hipotesis penelitian yaitu dari hasil perhitungan didapat nilai $t^{\prime}=6,02$ sehingga $t^{\prime}>t>-t$, dimana kriteria pengujian hipotesis adalah $\mathrm{H}_{0}$ dapat diterima jika $-\mathrm{t}>\mathrm{t}$ ' $>\mathrm{t}$. Hasil tersebut menunjukkan bahwa terdapat perbedaan yang signifikan hasil belajar siswa antara kelas eksperimen yang menggunakan multimedia interaktif dengan kelas kontrol yang menggunakan media visual pada kompetensi perbaikan differential.

Penggunaan multimedia interaktif pada kompetensi perbaikan differential ternyata memberikan pengaruh yang sangat besar terhadap peningkatan hasil belajar siswa hali ini dikarenakan multimedia ini mampu menampilkan materi-materi differential. Mampu menampilkan objek-objek yang sebenarnya tidak ada secara fisik atau diistilahkan dengan imagery. Secara kognitif pembelajaran dengan menggunakan mental imagery akan meningkatkan retensi siswa dalam mengingat materi-materi pelajaran (Munadi, 2008).

Hal ini, karena siswa langsung berinteraktif dan juga adanya tayangan menarik juga adanya animasi dapat membuat siswa tertarik untuk belajar materi pelajaran yang diberikan. Pemakaian media pembelajaran dalam proses belajar dapat membangkitkan keinginan dan minat yang baru, membangkitkan motivasi dan rangsangan kegiatan belajar, dan bahkan membawa pengaruh psikologis terhadap siswa (Arsyad, 2010).

Berdasarkan hasil penelitian dapat memberikan gambaran bahwa penggunaan multimedia interaktif dapat dijadikan media pembelajaran yang dapat membantu meningkatkan pemahaman siswa menjadi lebih baik. Bila yang diajarkan adalah suatu proses, maka media gerak seperti video, animasi, film atau televisi merupakan pilihan yang sesuai'. Multimedia interaktif banyak sekali memiliki kelebihan terutama dengan tampilan yang menarik bagi siswa sehingga dengan ini siswa dapat lebih terangsang untuk dapat mempelajari materi pelajaran yang disampaikan (Wibawa dan Mukti, 1991).

\section{KESIMPULAN}

Kesimpulkan penelitian ini yaitu: rata-rata hasil belajar siswa setelah melakukan proses pembelajaran kompetensi perbaikan differential menggunakan multimedia interaktif berada 
pada interpretasi cukup. Rata-rata hasil belajar siswa pada pembelajaran perbaikan differential menggunakan media visual berada pada interpretasi kurang. Pembelajaran menggunakan multimedia interaktif memberikan pengaruh yang signifikan terhadap hasil belajar siswa pada kompetensi perbaikan differential. Hasil belajar siswa pada kelas eksperimen yang menggunakan multimedia interaktif lebih besar dibandingkan peningkatan hasil belajar siswa yang menggunakan media visual.

\section{DAFTAR PUSTAKA}

Arsyad, A. (2010). Media pembelajaran. Jakarta: PT. Raja Grafindo Persada.

Munadi, Y. (2008). Media Pembelajaran. Jakarta: Gaung Persada Press.

Musfiqon. (2012). Pengembangan Media dan Sumber Pembelajaran. Jakarta: Prestasi Pustakarya.

Sadiman. (2008). Media Pendidikan. Jakarta: PT. Raja Grafindo Persada.

Wibawa, B., dan Mukti, F. (1991). Media Pengajaran. Jakarta: Departemen Pendidikan dan Kebudayaan. 